•数据论文・

\title{
罗霄山脉种子植物区系的特有现象与残遗现象
}

\author{
赵万义 ${ }^{1}$ 刘忠成 ${ }^{1,2}$ 王 蕾 ${ }^{2}$ 凡 强 ${ }^{*}$ 刘 佳 $^{1}$ 廖文波 $^{1^{*}}$ \\ 1 (中山大学生命科学学院有害生物控制与资源利用国家重点实验室/广东省热带亚热带植物资源重点实验室, 广州 510275) \\ 2 (首都师范大学资源环境与旅游学院, 北京 100048)
}

摘要: 罗霄山脉种子植物区系非常丰富, 是连接华东、华南、华中植物区系的重要通道, 区系组成具有明显的古 老性和过渡性特征。本文针对该区域种子植物的特有现象和残遗现象, 分析了其组成特点及形成原因。结果表明: (1)罗霄山脉共有中国特有科3科, 特有属55属, 特有种1,624种, 罗霄山脉区域特有种43种7变种; 特有属中以古特 有属为主，并以温带成分占优势(达55.91\%), 体现出明显的古老性和子遗性。(2)罗霄山脉共有子遗属165属, 以热 带亚洲分布、东亚-北美间断分布、东亚特有及中国特有成分为主，包括木本属132属。(3)受中新世气候波动以及 第四纪冰期的影响, 许多北方热带植物群的常绿成分、北极-第三纪的落叶成分, 在罗霄山脉得以保存下来成为古 特有和子遗成分。特有现象、残遗现象的分析结果表明罗霄山脉是一个重要的生物避难所, 其对中国东部植物区 系的保存和重新扩散具有重要意义。

关键词: 罗霄山脉; 特有现象; 残遗现象; 子遗属; 生物避难所

\section{The endemism and relict property of spermatophyte flora of the Luoxiao Mountains}

\author{
Wanyi Zhao ${ }^{1}$, Zhongcheng Liu ${ }^{1,2}$, Lei Wang ${ }^{2}$, Qiang Fan ${ }^{1 *}$, Jia Liu ${ }^{1}$, Wenbo Liao ${ }^{1 *}$ \\ 1 State Key Laboratory of Biocontrol, Guangdong Provincial Key Laboratory of Plant Resources, School of Life \\ Sciences, Sun Yat-sen University, Guangzhou 510275 \\ 2 College of Resource Environment and Tourism, Capital Normal University, Beijing 100048
}

\begin{abstract}
The Luoxiao Mountains with a bundant spermatophyte flora, which is an important channel connecting the flora of East, South and Centre of China, and was characterized by an prominent antiquity and relict property. This study focuses on endemic and relict genera or species in the Luoxiao Mountains by analyzing their composition, geographical structure and formation. (1) The results show that 3 families, 55 genera and 1,624 species are endemic to China within the Luoxiao Mountains; and 43 species and 7 varieties are endemic to the Luoxiao Mountains. Among the endemic genera, the palaeoendemic and relict genera account for a large proportion, which was dominated by temperate elements (account for $55.91 \%$ of total of endemic genera). (2) There are 165 relict genera in the Luoxiao Mountains, including 132 woody genera, and they mainly dominated by a tropics Asia dirtribution genera, East Asian-North American disjuncted distribution genera, East Asian endemic genera and Chinese endemic genera. (3) Additionally, due to climate fluctuations after the Miocene Epoch and during the Quaternary glacial period, the Luoxiao Mountains appears to have inherited a abundant evergreen northern tropical flora and deciduous Arctic or Northern-Tertiary flora. The analysis of endemic and relict characteristic implies that the Luoxiao Mountains is an important biological refuge, which is important to preserve and rediffusion of the flora of eastern China.
\end{abstract}

Key words: the Luoxiao Mountains; endemism; relict property; relict genus; biological refuge

植物区系地理学是研究一个大陆、一个国家或 地区植物区系组成和特点的分支学科(吴征镒等,
2006), 其最主要的目标是揭示植物区系的地理成 分、发生成分、迁移成分、历史成分及生态成分的

收稿日期: 2019-08-20; 接受日期: 2020-02-20

基金项目: 国家科技基础性工作专项(2013FY111500)和中山大学2014-2019年度广东省高等学校教学质量和教学改革工程项目

* 共同通讯作者 Co-authors for correspondence. E-mail: lsslwb@mail.sysu.edu.cn; fanqiang@mail.sysu.edu.cn 
组成和分化(王荷生, 1992)。特有现象及残遗现象的 形成具有明显的区域性, 与地质变迁及古气候波动 密切相关, 对于揭示区域生物群历史地理演化途径 有着重要作用(Kier et al, 2009; Feng et al, 2016), 是 植物区系研究中的重要内容(张光富, 2001)。

特有现象的研究对于植物区系区划和植被区 划具有重要价值(应俊生和陈梦玲, 2011)。根据特有 现象形成的历史，可将其分为古特有及新特有 (Engler, 1882; Wulff \& Brissenden, 1943)。很显然古 特有在追溯区域植物的区系发生历史时可作为一 个重要的指标(Wulff \& Brissenden, 1943; 应俊生和 张玉龙，1994)。应俊生和张玉龙(1994)对中国特有 属进行了系统的研究，提出了确认古特有属的 4 个 要点, 即: 可靠的化石证据、系统发生上的相对古 老性、属内间断分布现象的存在、木本生活型。

子遗种(relict species)是指在地质时期的生物类 群, 经历地质历史变迁之后几乎灭绝而仅残留个别 类群的现象(Lomolino et al, 2006)。子遗种体现了区 系发生与古地理、古环境有密切关系; 子遗种(属) 的组成可在一定程度上揭示一个地区植物区系的 整体发生历史。子遗种(属)常被划分为两个类型，即 分类学子遗种和地理学子遗种, 分类学子遗种指那 些系统发生古老、现代种系极为孤立的类群 (Lomolino et al, 2006; 廖文波等, 2014), 而地理学 子遗种通常指那些在历史上有着广泛分布, 而现在 分布区仅局限于狭窄范围、具有较长演化历史的类 群或其后裔(Wulff \& Brissenden, 1943; Lomolino et al, 2006; Habel \& Assmann, 2010; 廖文波等, 2014)。

罗霄山脉位于江西、湖南、湖北三省交界处, 地 理范围为 $113^{\circ} 17^{\prime}-116^{\circ} 09^{\prime} \mathrm{E} ; 2^{\circ} 30^{\prime}-29^{\circ} 59^{\prime} \mathrm{N}$, 北抵 长江, 南部与南岭山脉相接, 南北纵长达 $516 \mathrm{~km}$, 为湘江流域、赣江流域上游集水区，气候带跨越中 亚热带及北亚热带(图1), 特殊的地理位置及多样化 的生境, 使得罗霄山脉成为重要的物种迁徙和交流 通道, 造就了区域内丰富的植物多样性, 其种子植 物数量达179科1,107属4,314种(廖文波等, 2014; 赵 万义, 2017)。针对罗霄山脉地区各独体山地植物区 系的性质(Wang et al, 2013)和特有现象(谢国文等, 1995; 廖铅生等, 2008; 季春峰等, 2010), 曾有零星 的研究报道, 然而有关特有成分、残遗成分的系统 研究仍属空白。本文以特有现象、残遗现象为研究 对象, 探讨罗霄山脉的区系性质及发生历史, 以期

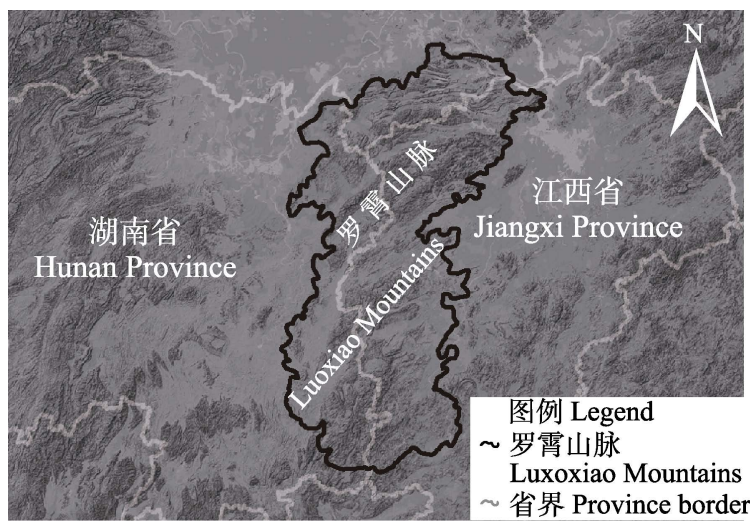

图1 罗霄山脉地理位置

Fig. 1 The geography location of the Luoxiao Mountains

为研究该地区的生物地理学史以及生态保护和管 理提供参考。

\section{种子植物区系数据收集及处理}

罗霄山脉种子植物区系数据是在赵万义(2017) 研究的基础上根据本次综合科学考察结果进一步 补充完善。并且参考近期出版的《中国生物物种名 录 (第一卷 植物 总名录I-III)》(王利松等, 2018) 及《中国维管植物科属词典》(李德铢等, 2018)两部 专著所采用的科、属概念统一拉丁名。中国特有科、 属的确定参考应俊生和张玉龙(1994)及吴征镒等 (2006)的原则，即包括分布区主体在中国但可延伸 至国境线外不远的一些科、属。中国特有种依据《中 国特有种子植物的多样性及其地理分布》(黄继红等, 2014)。罗霄山脉地区特有种依据《江西植物志》(江 西植物志编委会, 2004, 2014)、《湖南植物志》(刘 克明, 2000; 李丙贵和刘林翰, 2010)、《江西种子植 物名录》(刘仁林等, 2010) 以及本次科考进行校订。 子遗属的确定主要参考廖文波等(2014)及 Tang等 (2018)的研究成果, 具体标准为: (1)历史时期广泛 分布，在新近纪及更早的地层中已出现化石记录; (2)化石记录缺失, 但属内种系不丰富, 分类地位孤 立，且表现出明显的洲际间断现象。种子植物属的 地理成分按照吴征镒等(2006)及李德铢等(2018)。

\section{罗霄山脉种子植物区系特有成乡}

2.1 科的特有现象

罗霄山脉共分布有 3 个中国特有科，均为单型 科。其中银杏科是东亚植物区系的重要表征科, 被 
认为是东亚起源的，并在第四纪之后成为中国特有 科(周浙昆和Momohara，2005)。杜仲科化石记录广 布于北半球(周浙昆和Momohara，2005), 目前其现 存野生种群多见于华中地区, 在罗霄山脉野生种群 见于江西武宁县和井冈山自然保护区境内。伯乐树 科在APG IV系统中归并入叠珠树科(APG IV, 2016), 但科内两个属的形态特征及演化历史均差异巨大 (王伟等, 2017), 因此仅包含伯乐树 (Bretschneidera sinensis) 1 种的原伯乐树科仍旧是罗霄山脉种子植 物区系的重要表征科。

\section{2 属的特有现象}

罗霄山脉共分布有中国特有属55属, 包含74种 (表1, 附录1), 单型属达29属。古特有属数量较多, 共 32 属，包括银杉属 (Cathaya)、白豆杉属
(Pseudotaxus)、大血藤属(Sargentodoxa)、杜仲属 (Eucommia)、青檀属 (Pteroceltis)、伞花树属 (Eurycorymbus)、伯乐树属(Bretschneidera)、青钱柳 属(Cyclocarya)、杉木属(Cunninghamia)、㾉椒树属 (Tapiscia)、半枫荷属(Semiliquidambar)、喜树属 (Camptotheca) 等, 其系统发育地位均较孤立, 但在 地质时期曾存在丰富的化石种。新特有属23属, 多 为草本植物，如阴山荠属(Yinshania)、小花苣苔属 (Chiritopsis)、秦岭藤属(Biondia)所包含的种系呈现 一定程度分化，且属内各种分布区均较为狭窄。

罗霄山脉地区的各中国特有属在地理分布上 主要跨华东、华南、华中、西南等 4 个地理区，根据 韦恩图分析可以看出其大部分集中分布于华东、华 南、华中，有21属的分布区可扩展至西南(图2)。55

表1 罗霄山脉地区的中国特有属及其所含种数(罗霄山脉/中国)

Table 1 Genera endemic to China and its species number (Luoxiao Mountains/China) in the Luoxiao Mountains

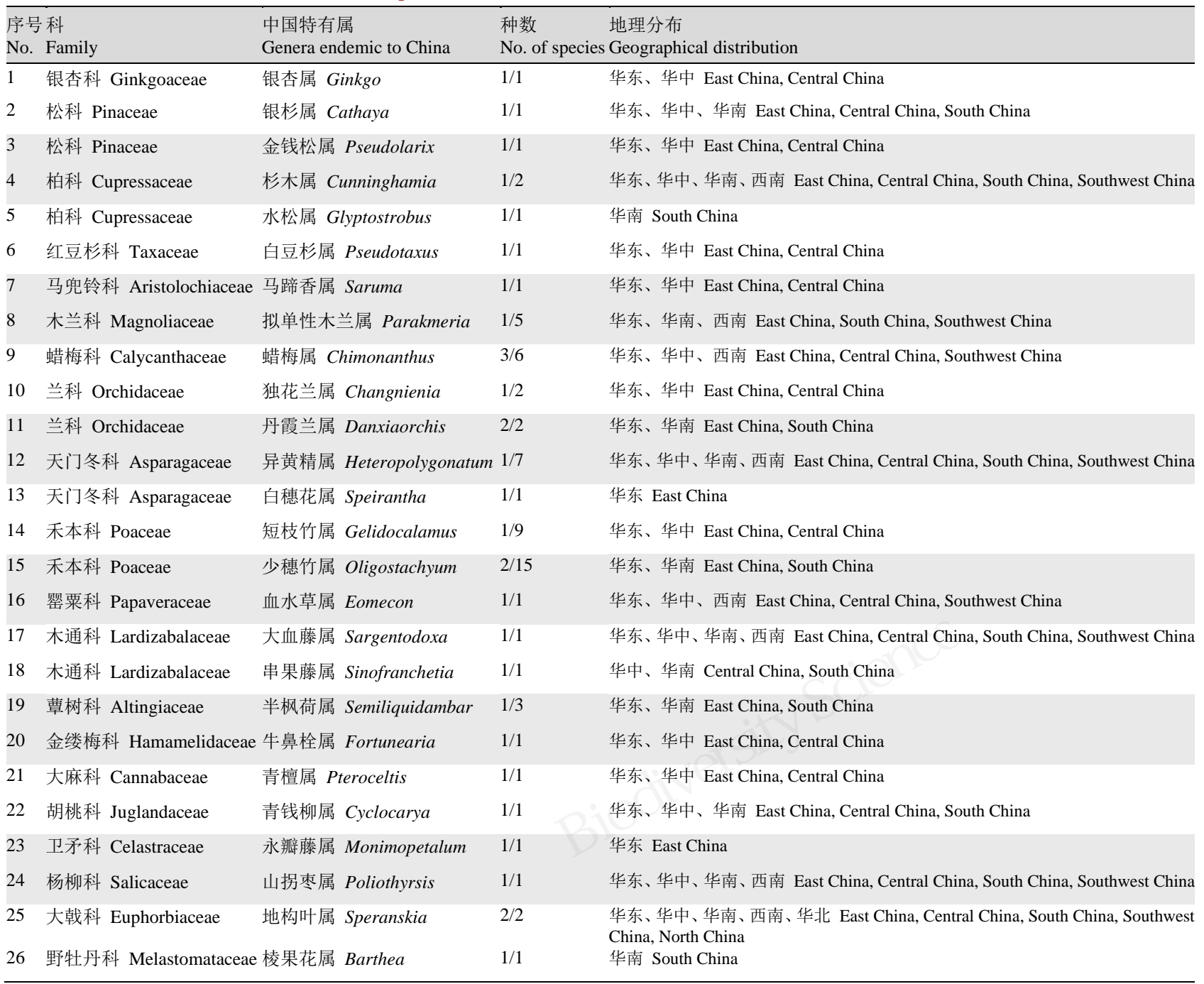


表1 (续) Table 1 (continued)

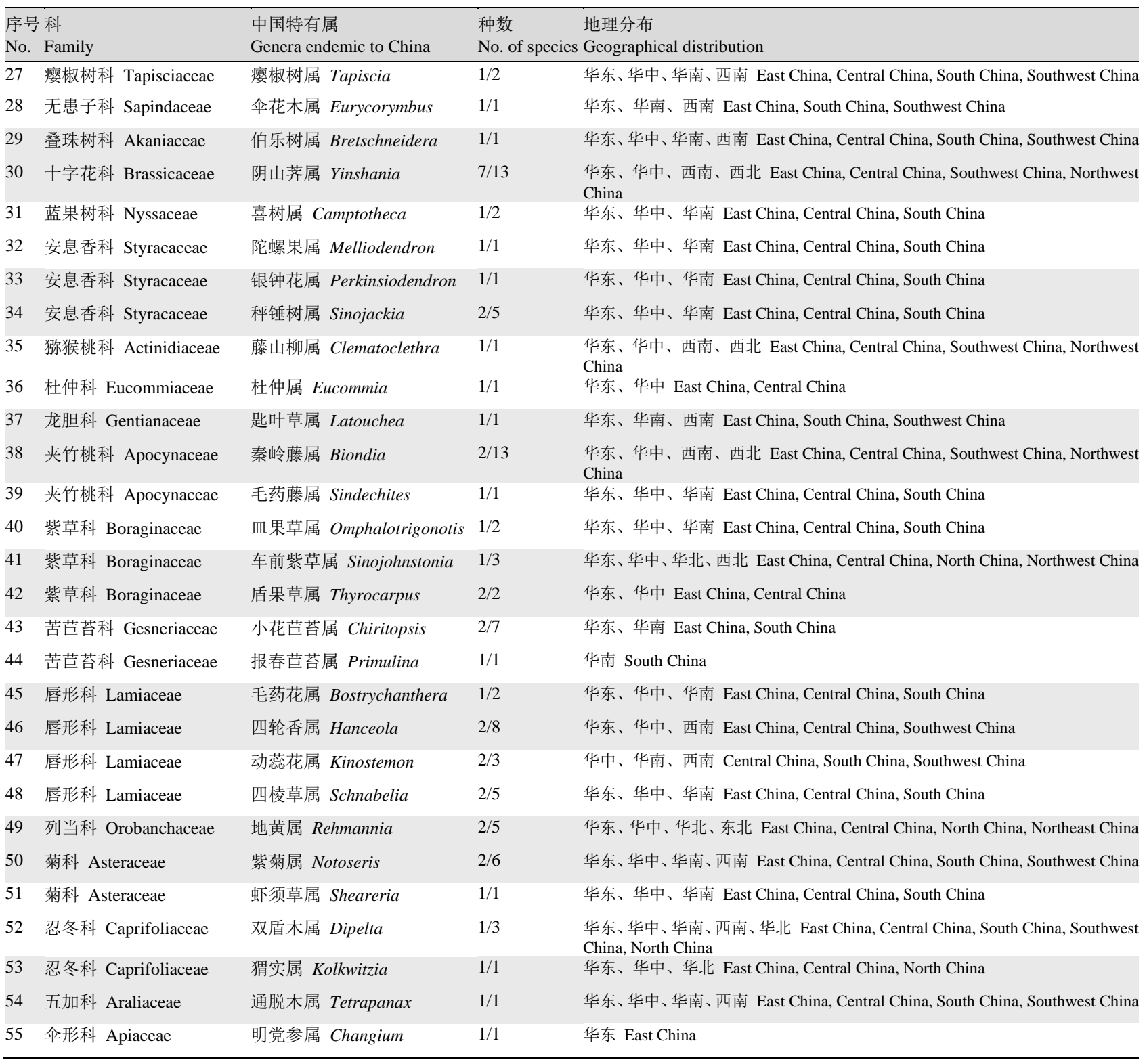

个特有属中, 有 11 属呈华东-华中-华南-西南分布 (图2), 如杉木属、痑椒树属、大血藤属、山拐衰属 (Poliothyrsis)、伯乐树属、通脱木属(Tetrapanax)、 异黄精属(Heteropolygonatum)、地构叶属(Speranskia) 等, 它们主产秦岭以南、横断山脉以东的广大地区, 体现出东亚植物区系是以中国大陆东部为主要核 心区的属性。有10属呈华东-华中-华南分布(表1, 图2), 广布于武夷山脉、罗霄山脉、南岭山脉及武 陵山脉, 分别是四棱草属(Schnabelia)、喜树属、血 果草属(Omphalotrigonotis)、银杉属、青钱柳属、陀 螺果属 (Melliodendron)、银 钟花属 (Perkinsiodendron)、秤锤树属(Sinojackia)、毛药藤

\section{属(Sindechites)和虾须草属(Sheareria)。}

13属呈华东-华中分布(表1, 图2), 即主产南岭 以北至秦岭以南地区，部分可向北延伸至西北、华 北地区, 分别是短枝竹属(Gelidocalamus)、独花兰 属(Changnienia)、盾果草属(Thyrocarpus)、银杏属 (Ginkgo)、金钱松属(Pseudolarix)、白豆杉属、马蹄 香属(Saruma)、牛鼻栓属(Fortunearia)、青檀属、杜 仲属、猬实属(Kolkwitzia)、地黄属(Rehmannia)和车 前紫草属(Sinojohnstonia)。

3属呈华东-华南-西南分布(表1, 图2), 分别是 少穗竹属(Oligostachyum)、小花苣苔属、半枫荷属。 4属为华东-华南分布(表1, 图2), 分别是丹霞兰属 


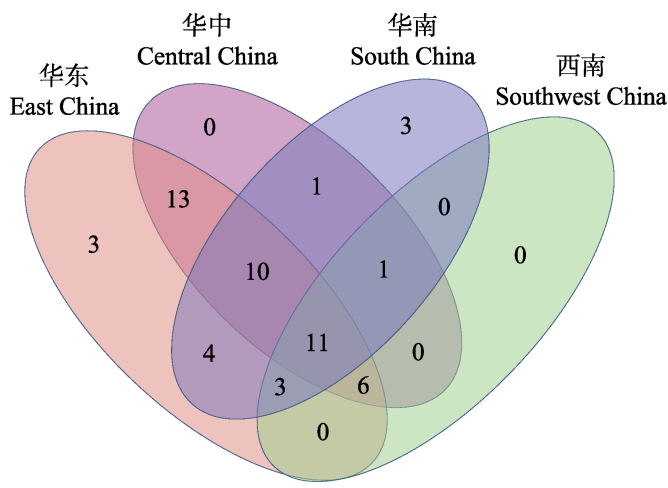

图2 罗霄山脉中国特有属分布韦恩图

Fig. 2 Venn diagram of Chinese endemic genera in the Luoxiao Mountains

(Danxiaorchis)、水松属(Glyptostrobus)、棱果花属 (Barthea) 和报春苣苔属(Primulina), 以上各属主要 分布于长江流域及以南。

有3属为华东区系特有属(表1, 图2), 其中白穗 花属(Speirantha)和明党参属(Changium)以浙皖山地 为分布中心, 向南延伸至罗霄山脉中部, 永瓣藤属 (Monimopetalum)分布于罗霄山脉北段及武夷山脉 北段, 为华东植物区系的典型代表(Wu \& Wu, 1996; 吴征镒等, 2010)。

\section{3 种的特有现象}

罗霄山脉种子植物特有种共计1,624种(附录2), 占中国特有种总数的 $10.76 \%$, 包括裸子植物 4 科 14 属18种, 被子植物 128 科 505 属1,606种。从特有种所 属科的数量结构来看, 罗霄山脉含 20 个以上中国特 有种的科有 25 个, 包括唇形科(87种)、蔷薇科(83 种)、樟科(62种)、杜鹃花科(49种)、壳斗科(45种)、 豆科(39种)、报春花科(38种)、兰科(36种)、冬青科 (34种)、毛茛科(34种)、葡萄科(31种)、苦菅苔科(28 种)、山茶科(27种)、绣求 科(26种)、五列木科(24种)、 五福花科(23种)、小檗科(23种)、天门冬科(22种)等。 这些包含中国特有种较丰富的科中, 大部分也是罗 霄山脉植物区系的优势科或表征科, 如蓄微科、杜 鹃花科、冬青科、葡萄科等(赵万义, 2017)。

整体上, 罗霄山脉包含中国特有种比例在 $50.00 \%$ 及以上的科有 56 科，除杜仲科、伯乐树科、 旌节花科等单型科或其种系在中国较稀少的科之 外，凤仙花科(特有化比例 $90.00 \%$ )、苦苣苔科 (87.50\%)、小檗科(85.19\%)、黄杨科(80.00\%)、杜鹃 花科 $(76.56 \%)$ 、马兒铃科 $(72.73 \%)$ 、绣球花科 (70.27\%)、安息香科(69.57\%)、猕猴桃科(68.57\%)、
金缕梅科(66.67\%)等包含种系较为丰富，其特有化 程度的比例远高于中国种子植物特有率 52.1\% (Huang et al, 2011), 反映出罗霄山脉地区植物区系 得到一定程度的分化。

\section{4 罗霄山脉地区本地特有种}

罗霄山脉共分布有本地特有种 43 种7变种, 分 别是江西小檗(Berberis jiangxiensis)、庐山景天 (Sedum lushanense)、细枝绣球(Hydrangea gracilis)、 多脉凤仙花(Impatiens polyneura)、封怀凤仙花(I. fenghwaiana)、井冈山木莲(Manglietia jinggangshanensis)、井冈栝楼(Trichosanthes jinggangshanica)、厚叶红山茶(Camellia crassissima)、汝城 毛叶茶(C. pubescens)、井冈山厚皮香(Ternstroemia aubrotundafolia)、尖叶猕猴桃(Actinidia callosa var. acuminata)、井冈山狝猴桃(A. chinensis var. jinggangshanensis)、井冈山绣线梅(Neillia jinggangshanensis)、膜叶椴(Tilia membranacea)、腺果悬钩 子(Rubus glandulosocarpus)、庐山山黑豆(Dumasia ovatifolia)、武功山冬青(Ilex wugongshanensis)、江 西羊奶子(Elaeagnus jiangxiensis)、井风葡萄(Vitis jinggangensis)、小果吴茱莫(Euodia rutaecarpa var. microcarpa)、九江三角槭(Acer buergerianum var. jiujiangse)、粗柱杜鹃(Rhododendron crassistylum)、 井冈山杜鹃 (R. jinggangshanicum)、上犹杜鹃 $(R$. seniavinii var. shangyoumicum)、伏毛杜鹃 ( $R$. strigosum)、庐山紫金牛(Ardisia ushanensis)、江西蒲儿 根(Sinosenecio jiangxiensis)、庐山疏节过路黄(Lysimachia remota var. lushanensis)、江西半蒴菅苔(Hemiboea subacaulis var. jiangxiensis)、永兴小花苣苔 (Chiritopsis yongxingensis)、花箨唐竹(Sinobambusa striata)、井冈寒竹(Gelidocalamus stellatus)、井冈唐 竹(Sinobambusa anaurita)、庐山玉山竹(Yushania varians)、九宫山细辛(Asarum campaniflorum)和井 冈山堇菜(Viola jinggangshanensis), 以及2013-2019 年间发表的新种，如桂东锦香草(Phyllagathis guidongensis)、遂川报春苣苔(Primulina suichuanensis)、衡山报春苣苔(P. hengshanensis)、张氏 野海棠(Bredia changii)、罗霄虎耳草(Saxifraga luoxiaoensis)、神农虎耳草(S. shennongii)、纤秀冬青 (Ilex venusta)、小果马银花(Rhododendron microcarpum)、湖北羽叶毛莨(Primula hubeiensis)、九宫 山羽叶毛莨(P. jiugongshanensis)、绿花白丝草 
(Chamaelirium viridiflorum)、杨氏丹霞兰 (Danxiaorchis yangii)、武功山春蓼(Persicaria wugongshanensis) 和武功山异黄精 (Heteropolygonatum wugongshanensis)。生境的异质性和多样化可能是罗 霄山脉地区特有现象较为丰富的重要原因。特有种 江西蒲儿根、小果马银花等均产海拔 $1,200 \mathrm{~m}$ 以上山 坡; 桂东锦香草、神农虎耳草、罗霄虎耳草仅见于 山谷溪边的阴湿石壁上; 而永兴小花苣苔、遂川报 春苣苔、衡山报春苣苔等则仅分布于丹霞地貌中。 罗霄山脉分布的各类区域特有种, 充分体现出保护 该地区自然环境的重要性, 而近年来不断发现的新 物种, 也说明进一步加强该地区生物多样性考察的 必要性。

\section{3 罗霄山脉种子植物区系残遗成分}

\section{1 子遗属的组成}

根据子遗种、子遗属的概念和甄别原则 (Lomolino et al, 2006; 廖文波等, 2014; Tang et al, 2018), 统计得出罗霄山脉地区共有子遗属165属 289 种, 其中裸子植物 19 属 27 种, 被子植物 147 属 262种(表2, 附录3)。从生态型上来看, 罗霄山脉地 区子遗属以木本属为主, 达 132 属, 草本属有33属。
此外, 单型属达46属, 寡种属(世界仅分布2-5种) 52 属, 表明本区子遗属具有明显的分类学子遗特征, 反映出罗霄山脉植物区系的古老性。

\section{2 子遗属的地理分布格局}

罗霄山脉地区的子遗属地理分布区类型组成 有: 世界广布属4属, 其中有3属为原始的水生植物, 即莼菜属(Brasenia)、荇菜属(Nymphoides)和睡莲属 (Nymphaea), 另有杜柳属(Periploca)广布于亚洲、欧 洲及热带非洲。热带性分布属32属，除去以美洲、 大洋洲为分布中心的罗汉松属(Podocarpus)、古柯 属 (Erythroxylum)、芭蕉属 (Musa)、无患子属 (Sapindus)外, 均为单型属或寡种属, 其中热带亚洲 分布属占25属。温带性分布属相当丰富, 共129属, 其中以东亚-北美间断分布属(31属)、东亚特有属 (50属)、中国特有属(30属)为主。

属的分布区类型、空间地理分布格局的分析结 果表明, 子遗属在罗霄山脉地区以及与中国子遗属 整体上的地理分布格局相一致(廖文波等, 2014), 即 以东亚-北美间断分布属、东亚特有属、中国特有 属、热带亚洲分布属占优势, 主要以东亚大陆东部、 南部为分布中心，是为典型的东亚植物区系成分 (吴征镒等, 2006)。

表2 罗霄山脉地区种子植物区系子遗属及其种数组成(罗霄山脉/中国/世界)

Table 2 Relict genera of spermatophyte flora and its species number (Luoxiao Mountains/China/world) in the Luoxiao Mountains

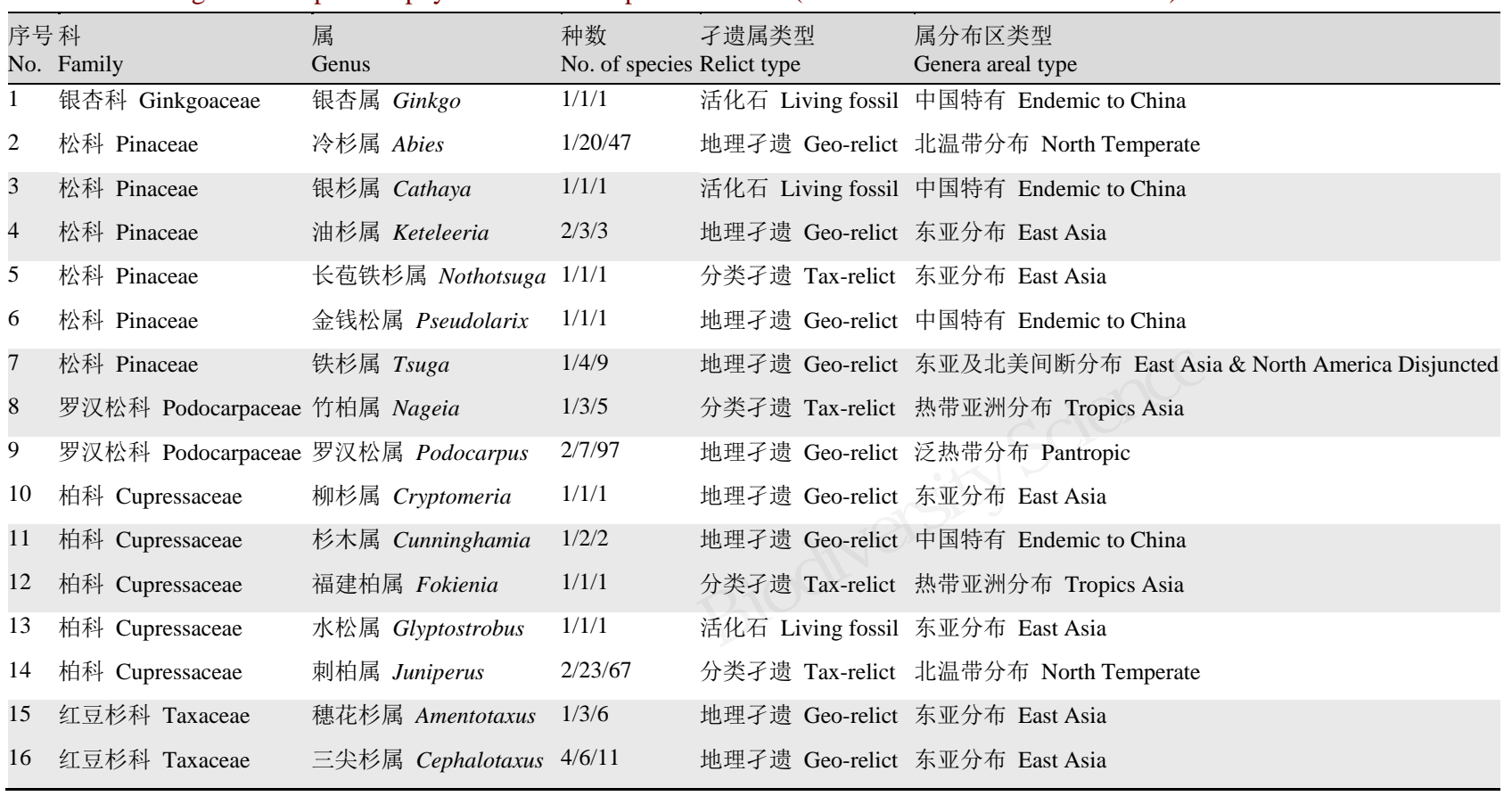


表2 (续) Table 2 (continued)

\begin{tabular}{|c|c|c|c|c|}
\hline \multicolumn{2}{|c|}{ 序号科 } & $\begin{array}{l}\text { 属 } \\
\text { Genus }\end{array}$ & $\begin{array}{l}\text { 种数 } \\
\text { No. of species }\end{array}$ & $\begin{array}{ll}\text { 子遗属类型 } & \text { 属分布区类型 } \\
\text { s Relict type } & \text { Genera areal type }\end{array}$ \\
\hline 17 & 红豆杉科 Taxaceae & 白豆杉属 Pseudotaxus & $1 / 1 / 1$ & 地理子遗 Geo-relict 中国特有 Endemic to China \\
\hline 18 & 红豆杉科 Taxaceae & 红豆杉属 Taxus & $1 / 7 / 12$ & 地理子遗 Geo-relict 北温带分布 North Temperate \\
\hline 19 & 红豆杉科 Taxaceae & 榧树属 Torreya & $1 / 4 / 6$ & 地理子遗 Geo-relict 东亚及北美间断分布 East Asia \& North America Disjuncted \\
\hline 20 & 莼菜科 Cabombaceae & 莼菜属 Brasenia & $1 / 1 / 1$ & 地理子遗 Geo-relict 世界广布 Cosmopolitan \\
\hline 21 & 睡莲科 Nymphaeaceae & 苋属 Euryale & $1 / 1 / 1$ & 分类子遗 Tax-relict 东亚分布 East Asia \\
\hline 22 & 睡莲科 Nymphaeaceae & 睡莲属 Nymphaea & $1 / 5 / 50$ & 分类子遗 Tax-relict 世界广布 Cosmopolitan \\
\hline 23 & 五味子科 Schisandraceae & e八角属 Illicium & $6 / 27 / 40$ & 分类子遗 Tax-relict 东亚及北美间断分布 East Asia \& North America Disjuncted \\
\hline 24 & 五味子科 Schisandraceae & e五味子属 Schisandra & $6 / 19 / 22$ & 分类子遗 Tax-relict 东亚及北美间断分布 East Asia \& North America Disjuncted \\
\hline 25 & 三白草科 Saururaceae & 三白草属 Saururus & $1 / 1 / 2$ & 分类子遗 Tax-relict 东亚及北美间断分布 East Asia \& North America Disjuncted \\
\hline 27 & 木兰科 Magnoliaceae & 鹅掌楸属 Liriodendron & $1 / 1 / 2$ & 分类子遗 Tax-relict 东亚及北美间断分布 East Asia \& North America Disjuncted \\
\hline 28 & 木兰科 Magnoliaceae & 厚朴属 Houpoёa & $1 / 3 / 9$ & 分类子遗 Tax-relict 东亚及北美间断分布 East Asia \& North America Disjuncted \\
\hline 29 & 木兰科 Magnoliaceae & 木莲属 Manglietia & $4 / 29 / 40$ & 地理子遗 Geo-relict 热带亚洲分布 Tropics Asia \\
\hline 30 & 木兰科 Magnoliaceae & 天女花属 Oyama & $1 / 4 / 4$ & 分类子遗 Tax-relict 东亚分布 East Asia \\
\hline 31 & 木兰科 Magnoliaceae & 拟单性木兰属 Parakmeria & $1 / 5 / 5$ & 分类子遗 Tax-relict 中国特有 Endemic to China \\
\hline 32 & 木兰科 Magnoliaceae & 玉兰属 Yulania & $6 / 18 / 25$ & 地理子遗 Geo-relict 东亚及北美间断分布 East Asia \& North America Disjuncted \\
\hline 33 & 蜡梅科 Calycanthaceae & 蜡梅属 Chimonanthus & $3 / 6 / 6$ & 地理子遗 Geo-relict 中国特有 Endemic to China \\
\hline 34 & 樟科 Lauraceae & 檫木属 Sassafras & $1 / 2 / 3$ & 地理子遗 Geo-relict 东亚及北美间断分布 East Asia \& North America Disjuncted \\
\hline 35 & 金粟兰科 Chloranthaceae & $\mathrm{e}$ 草珊瑚属 Sarcandra & $1 / 2 / 3$ & 分类子遗 Tax-relict 热带亚洲分布 Tropics Asia \\
\hline 36 & 菖蒲科 Acoraceae & 菖蒲属 Acorus & $2 / 2 / 2$ & 分类子遗 Tax-relict 东亚及北美间断分布 East Asia \& North America Disjuncted \\
\hline 38 & 无叶莲科 Petrosaviaceae & 无叶莲属 Petrosavia & $1 / 2 / 3$ & 地理子遗 Geo-relict 热带亚洲分布 Tropics Asia \\
\hline 39 & 薯蓣科 Dioscoreaceae & 裂果薯属 Schizocapsa & $1 / 2 / 2$ & 分类子遗 Tax-relict 热带亚洲分布 Tropics Asia \\
\hline 40 & 藜芦科 Melanthiaceae & Y芯花属 Ypsilandra & $1 / 4 / 5$ & 地理子遗 Geo-relict 东亚分布 East Asia \\
\hline 41 & 秋水仙科 Colchicaceae & 万寿竹属 Disporum & $7 / 15 / 21$ & 地理子遗 Geo-relict 东亚分布 East Asia \\
\hline 42 & 天门冬科 Asparagaceae & 绵柊儿属 Barnardia & $1 / 1 / 2$ & 地理子遗 Geo-relict 旧世界温带分布 Old World Temperate \\
\hline 43 & 棕㭣科 Arecaceae & 棕㭣属 Trachycarpus & $1 / 3 / 8$ & 分类子遗 Tax-relict 东亚分布 East Asia \\
\hline 44 & 鸭跖草科 Commelinaceae & 竹叶吉祥草属 Spatholirion & $n 1 / 2 / 3$ & 地理子遗 Geo-relict 热带亚洲分布 Tropics Asia \\
\hline 45 & 芭蕉科 Musaceae & 芭蕉属 Musa & $1 / 11 / 30$ & 地理子遗 Geo-relict 旧世界热带分布 Old World Tropics \\
\hline 46 & 领春木科 Eupteleaceae & 领春木属 Euptelea & $1 / 1 / 2$ & 分类子遗 Tax-relict 东亚分布 East Asia \\
\hline 47 & 罂粟科 Papaveraceae & 血水草属 Eomecon & $1 / 1 / 1$ & 地理子遗 Geo-relict 中国特有 Endemic to China \\
\hline 48 & 罂粟科 Papaveraceae & 荷青花属 Hylomecon & $1 / 1 / 1$ & 地理子遗 Geo-relict 东亚分布 East Asia \\
\hline 49 & 木通科 Lardizabalaceae & 木通属 Akebia & $4 / 5 / 6$ & 分类子遗 Tax-relict 东亚分布 East Asia \\
\hline 50 & 木通科 Lardizabalaceae & 猫儿屎属 Decaisnea & $1 / 1 / 1$ & 地理子遗 Geo-relict 东亚分布 East Asia \\
\hline 51 & 木通科 Lardizabalaceae & 大血藤属 Sargentodoxa & $1 / 1 / 1$ & 分类子遗 Tax-relict 热带亚洲分布 Tropics Asia \\
\hline 52 & 木通科 Lardizabalaceae & 串果藤属 Sinofranchetia & $1 / 1 / 1$ & 地理子遗 Geo-relict 中国特有 Endemic to China \\
\hline 53 & 防己科 Menispermaceae & 蝙蝠葛属 Menispermum & $1 / 1 / 4$ & 分类子遗 Tax-relict 东亚及北美间断分布 East Asia \& North America Disjuncted \\
\hline 54 & 防己科 Menispermaceae & 风龙属 Sinomenium & $1 / 1 / 2$ & 分类子遗 Tax-relict 东亚分布 East Asia \\
\hline 55 & 小檗科 Berberidaceae & 鬼臼属 Dysosma & $2 / 7 / 7$ & 地理子遗 Geo-relict 东亚分布 East Asia \\
\hline 56 & 小檗科 Berberidaceae & 南天竹属 Nandina & $1 / 1 / 1$ & 地理子遗 Geo-relict 东亚分布 East Asia \\
\hline 57 & 小檗科 Berberidaceae & 桃儿七属 Sinopodophyllum & $n 1 / 1 / 2$ & 地理子遗 Geo-relict 东亚分布 East Asia \\
\hline
\end{tabular}


表2 (续) Table 2 (continued)

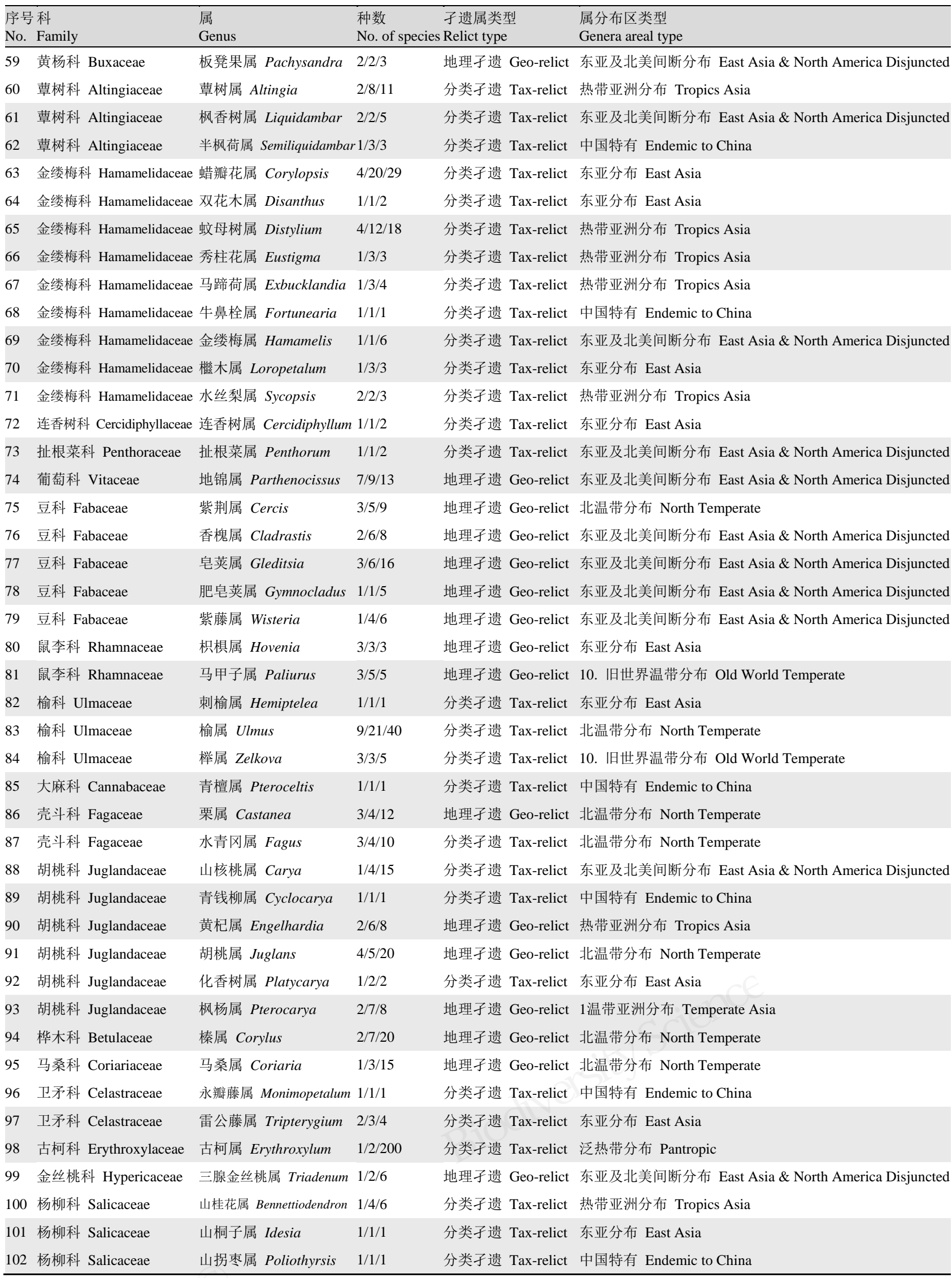


表2 (续) Table 2 (continued)

\begin{tabular}{|c|c|c|c|c|c|}
\hline $\begin{array}{l}\text { 序号 } \\
\text { No. }\end{array}$ & $\begin{array}{l}\text { Family } \\
\text { Fat }\end{array}$ & $\begin{array}{l}\text { 属 } \\
\text { Genus } \\
\end{array}$ & $\begin{array}{l}\text { 种数 } \\
\text { No. of species }\end{array}$ & $\begin{array}{l}\text { 子遗属类型 } \\
\text { Relict type }\end{array}$ & $\begin{array}{l}\text { 属分布区类型 } \\
\text { Genera areal type }\end{array}$ \\
\hline 103 & 叶下珠科 Phyllanthaceae & 秋枫属 Bischofia & $1 / 2 / 2$ & 分类子遗 Tax-relict & 热带亚洲分布 Tropics Asia \\
\hline 104 & 野牡丹科 Melastomataceae & 棱果花属 Barthea & $1 / 1 / 1$ & 地理子遗 Geo-relict & 中国特有 Endemic to China \\
\hline 105 & 省沽油科 Staphyleaceae & 野鸦椿属 Euscaphis & $2 / 1 / 1$ & 地理子遗 Geo-relict & 东亚分布 East Asia \\
\hline 106 & 省沽油科 Staphyleaceae & 省沽油属 Staphylea & $2 / 6 / 13$ & 地理子遗 Geo-relict & 北温带分布 North Temperate \\
\hline 107 & 旌节花科 Stachyuraceae & 旌节花属 Stachyurus & $2 / 7 / 8$ & 地理子遗 Geo-relict & 东亚分布 East Asia \\
\hline 108 & 痑椒树科 Tapisciaceae & 瘞椒树属 Tapiscia & $1 / 2 / 6$ & 地理子遗 Geo-relict & 中国特有 Endemic to China \\
\hline 109 & 漆树科 Anacardiaceae & 南酸東属 Choerospondias & $1 / 1 / 1$ & 分类子遗 Tax-relict & 东亚分布 East Asia \\
\hline 110 & 无患子科 Sapindaceae & 七叶树属 Aesculus & $1 / 4 / 13$ & 分类子遗 Tax-relict & 北温带分布 North Temperate \\
\hline 111 & 无患子科 Sapindaceae & 企花木属 Eurycorymbus & $1 / 1 / 1$ & 地理子遗 Geo-relict & 中国特有 Endemic to China \\
\hline 112 & 无患子科 Sapindaceae & 榇属 Koelreuteria & $1 / 3 / 4$ & 分类子遗 Tax-relict & 东亚分布 East Asia \\
\hline 113 & 无患子科 Sapindaceae & 无患子属 Sapindus & $1 / 4 / 10$ & 地理子遗 Geo-relict & $\begin{array}{l}\text { 东亚(热带、亚热带)和热带南美间断分布 Tropics \& } \\
\text { Subtropics East Asia \& Tropical America Disjuncted }\end{array}$ \\
\hline 114 & 芸香科 Rutaceae & 臭常山属 Orixa & $1 / 1 / 1$ & 地理子遗 Geo-relict & 东亚分布 East Asia \\
\hline 115 & 芸香科 Rutaceae & 黄檗属 Phellodendron & $2 / 2 / 4$ & 地理子遗 Geo-relict & 东亚分布 East Asia \\
\hline 116 & 芸香科 Rutaceae & 茵芋属 Skimmia & $1 / 5 / 6$ & 地理子遗 Geo-relict & 东亚分布 East Asia \\
\hline 117 & 芸香科 Rutaceae & 飞龙掌血属 Toddalia & $1 / 1 / 1$ & 地理子遗 Geo-relict & 热带亚洲至热带非洲分布 Tropics Asia to Tropics Africa \\
\hline 118 & 苦木科 Simaroubaceae & 苦木属 Picrasma & $1 / 2 / 9$ & 地理子遗 Geo-relict & $\begin{array}{l}\text { 东亚(热带、亚热带)和热带南美间断分布 Tropics \& } \\
\text { Subtropics East Asia \& Tropical America Disjuncted }\end{array}$ \\
\hline 119 & 锦葵科 Malvaceae & 梧桐属 Firmiana & $1 / 7 / 16$ & 分类子遗 Tax-relict & 东亚分布 East Asia \\
\hline 120 & 锦葵科 Malvaceae & 梭罗树属 Reevesia & $2 / 15 / 25$ & 地理子遗 Geo-relict & 热带亚洲分布 Tropics Asia \\
\hline 121 & 叠珠树科 Akaniaceae & 伯乐树属 Bretschneidera & $a 1 / 1 / 1$ & 分类子遗 Tax-relict & 热带亚洲分布 Tropics Asia \\
\hline 122 & 檀香科 Santalaceae & 檀梨属 Pyrularia & $1 / 1 / 2$ & 地理子遗 Geo-relict & 东亚及北美间断分布 East Asia \& North America Disjuncted \\
\hline 123 & 蓝果树科 Nyssaceae & 喜树属 Camptotheca & $1 / 2 / 2$ & 分类子遗 Tax-relict & 中国特有 Endemic to China \\
\hline 124 & 蓝果树科 Nyssaceae & 蓝果树属 Nyssa & $1 / 3 / 7$ & 地理子遗 Geo-relict & 东亚及北美间断分布 East Asia \& North America Disjuncted \\
\hline 125 & 绣球科 Hydrangeaceae & 草绣球属 Cardiandra & $1 / 2 / 3$ & 地理子遗 Geo-relict & 东亚分布 East Asia \\
\hline 126 & 绣球科 Hydrangeaceae & 蛛网莤属 Platycrater & $1 / 1 / 1$ & 分类子遗 Tax-relict & 东亚分布 East Asia \\
\hline 127 & 绣球科 Hydrangeaceae & 钻地风属 Schizophragma & $4 / 6 / 7$ & 地理子遗 Geo-relict & 东亚分布 East Asia \\
\hline 128 & 山荣英科 Cornaceae & 山荣英属 Cornus & $12 / 25 / 55$ & 分类子遗 Tax-relict & 北温带分布 North Temperate \\
\hline 129 & 五列木科 Pentaphylacaceae & e茶梨属 Anneslea & $1 / 1 / 3$ & 分类子遗 Tax-relict & 热带亚洲分布 Tropics Asia \\
\hline 130 & 五列木科 Pentaphylacaceae & e五列木属 Pentaphylax & $1 / 1 / 1$ & 分类子遗 Tax-relict & 热带亚洲分布 Tropics Asia \\
\hline 131 & 山茶科 Theaceae & 紫茎属 Stewartia & $5 / 15 / 20$ & 地理子遗 Geo-relict & 东亚及北美间断分布 East Asia \& North America Disjuncted \\
\hline 132 & 安息香科 Styracaceae & 赤杨叶属 Alniphyllum & $1 / 3 / 3$ & 地理子遗 Geo-relict & 热带亚洲分布 Tropics Asia \\
\hline 133 & 安息香科 Styracaceae & 山茉莉属 Huodendron & $1 / 3 / 4$ & 分类子遗 Tax-relict & 热带亚洲分布 Tropics Asia \\
\hline 134 & 安息香科 Styracaceae & 陀螺果属 Melliodendron & $1 / 1 / 1$ & 地理子遗 Geo-relict & 中国特有 Endemic to China \\
\hline 135 & 安息香科 Styracaceae & 银钟花属 Perkinsiodendron & $1 / 1 / 1$ & 分类子遗 Tax-relict & 中国特有 Endemic to China \\
\hline 136 & 安息香科 Styracaceae & 白辛树属 Pterostyrax & $2 / 2 / 3$ & 地理子遗 Geo-relict & 东亚分布 East Asia \\
\hline 137 & 安息香科 Styracaceae & 木瓜红属 Rehderodendron & $1 / 5 / 6$ & 地理子遗 Geo-relict & 东亚分布 East Asia \\
\hline 138 & 安息香科 Styracaceae & 秤锤树属 Sinojackia & $2 / 5 / 5$ & 地理子遗 Geo-relict & 中国特有 Endemic to China \\
\hline 139 & 猕猴桃科 Actinidiaceae & 藤山柳属 Clematoclethra & $1 / 1 / 1$ & 分类子遗 Tax-relict & 中国特有 Endemic to China \\
\hline 140 & 杜鹃花科 Ericaceae & 吊钟花属 Enkianthus & $3 / 7 / 12$ & 分类子遗 Tax-relict & 东亚分布 East Asia \\
\hline 141 & 杜鹃花科 Ericaceae & 珍珠花属 Lyonia & $1 / 5 / 6$ & 分类子遗 Tax-relict & 东亚及北美间断分布 East Asia \& North America Disjuncted \\
\hline 142 & 杜鹃花科 Ericaceae & 假沙晶兰属 Monotropastrum & $1 / 2 / 2$ & 分类子遗 Tax-relict & 热带亚洲分布 Tropics Asia \\
\hline 143 & 杜仲科 Eucommiaceae & 杜仲属 Eucommia & $1 / 1 / 1$ & 分类子遗 Tax-relict & 中国特有 Endemic to China \\
\hline 144 & 丝缨花科 Garryaceae & 桃叶珊瑚属 Aucuba & $4 / 10 / 10$ & 地理子遗 Geo-relict & 东亚分布 East Asia \\
\hline 145 & 茜草科 Rubiaceae & 香果树属 Emmenopterys & $1 / 1 / 1$ & 地理子遗 Geo-relict & 热带亚洲分布 Tropics Asia \\
\hline 146 & 钩吻科 Gelsemiaceae & 钩吻属 Gelsemium & $1 / 1 / 3$ & 地理子遗 Geo-relict & 东亚及北美间断分布 East Asia \& North America Disjuncted \\
\hline 147 & 夹竹桃科 Apocynaceae & 杜柳属 Periploca & $1 / 6 / 10$ & 地理子遗 Geo-relict & 世界广布 Cosmopolitan \\
\hline 148 & 夹竹桃科 Apocynaceae & 毛药藤属 Sindechites & $1 / 1 / 1$ & 地理子遗 Geo-relict & 中国特有 Endemic to China \\
\hline 149 & 木犀科 Oleaceae & 流苏树属 Chionanthus & $2 / 7 / 80$ & 地理子遗 Geo-relict & 东亚及北美间断分布 East Asia \& North America Disjuncted \\
\hline 150 & 车前科 Plantaginaceae & 幌菊属 Ellisiophyllum & $1 / 1 / 1$ & 地理子遗 Geo-relict & 热带亚洲分布 Tropics Asia \\
\hline
\end{tabular}


表2 (续) Table 2 (continued)

\begin{tabular}{|c|c|c|c|c|c|}
\hline 序号 & $\begin{array}{l}\text { 科 } \\
\text { Family }\end{array}$ & $\begin{array}{l}\text { 属 } \\
\text { Genus }\end{array}$ & $\begin{array}{l}\text { 种数 } \\
\text { No. of species }\end{array}$ & $\begin{array}{l}\text { 子遗属类型 } \\
\text { Relict type }\end{array}$ & $\begin{array}{l}\text { 属分布区类型 } \\
\text { Genera areal type }\end{array}$ \\
\hline 151 & 车前科 Plantaginaceae & 茶菱属 Trapella & $1 / 1 / 2$ & 地理子遗 Geo-relict & 东亚分布 East Asia \\
\hline 152 & 紫葳科 Bignoniaceae & 梓属 Catalpa & $1 / 4 / 13$ & 分类子遗 Tax-relict & 东亚及北美间断分布 East Asia \& North America Disjuncted \\
\hline 153 & 唇形科 Lamiaceae & 毛药花属 Bostrychanthera & $1 / 2 / 2$ & 地理子遗 Geo-relict & 中国特有 Endemic to China \\
\hline 154 & 透骨草科 Phrymaceae & 透骨草属 Phryma & $1 / 1 / 1$ & 地理子遗 Geo-relict & 东亚及北美间断分布 East Asia \& North America Disjuncted \\
\hline 155 & 泡桐科 Paulowniaceae & 泡桐属 Paulownia & $4 / 6 / 7$ & 地理子遗 Geo-relict & 东亚分布 East Asia \\
\hline 156 & 青荚叶科 Helwingiaceae & 青荚叶属 Helwingia & $2 / 4 / 4$ & 分类子遗 Tax-relict & 东亚分布 East Asia \\
\hline 157 & 五福花科 Adoxaceae & 接骨木属 Sambucus & $2 / 4 / 10$ & 地理子遗 Geo-relict & 北温带分布 North Temperate \\
\hline 158 & 桔梗科 Campanulaceae & 袋果草属 Peracarpa & $1 / 1 / 1$ & 分类子遗 Tax-relict & 东亚分布 East Asia \\
\hline 159 & 睡菜科 Menyanthaceae & 荇菜属 Nymphoides & $3 / 6 / 57$ & 分类子遗 Tax-relict & 世界广布 Cosmopolitan \\
\hline 160 & 忍冬科 Caprifoliaceae & 双盾木属 Dipelta & $1 / 3 / 3$ & 地理子遗 Geo-relict & 中国特有 Endemic to China \\
\hline 161 & 忍冬科 Caprifoliaceae & 猬实属 Kolkwitzia & $1 / 1 / 1$ & 分类子遗 Tax-relict & 中国特有 Endemic to China \\
\hline 162 & 忍冬科 Caprifoliaceae & 锦带花属 Weigela & $2 / 2 / 10$ & 分类子遗 Tax-relict & 东亚分布 East Asia \\
\hline 163 & 五加科 Araliaceae & 刺楸属 Kalopanax & $1 / 1 / 1$ & 分类子遗 Tax-relict & 东亚分布 East Asia \\
\hline 164 & 五加科 Araliaceae & 人参属 Panax & $2 / 8 / 11$ & 分类子遗 Tax-relict & 东亚及北美间断分布 East Asia \& North America Disjuncted \\
\hline 165 & 五加科 Araliaceae & 通脱木属 Tetrapanax & $1 / 1 / 1$ & 地理子遗 Geo-relict & 中国特有 Endemic to China \\
\hline
\end{tabular}

\section{4 罗霄山脉植物区系的残遗性}

以中国大陆为主体的东亚地区，尤其是东南部 亚热带季风区, 是第三纪子遗属、特有属的重要保 存中心(Milne \& Abbott, 2002; Qian \& Ricklefs, 2004; Tang et al, 2018), 那些特征属是中国东南部亚热带 植物区系的重要特征(沈泽昊和张新时, 2000)。罗霄 山脉分布有子遗属 165 属, 占罗霄山脉总属数的 14.90\%, 充分体现了其区系的古老性、残遗性。本 地区分布的 55 个中国特有属, 同样以具有木本生 态型的古特有属占优势, 如银杉属、银杏属、青檀 属、伯乐树属等, 在地质时期均具有丰富而广泛的 化石记录, 无疑地处中国东南部季风区的罗霄山脉 是重要的第三纪子遗植物群重要的保存地之一。

罗霄山脉地区所分布的子遗属、古特有属是第 三纪时期的北方热带植物群 (boreotropical flora) (Wolfe，1975)及北极-第三纪植物群(Arcto-Tertiary flora) (Engler, 1879; Mai, 1991)的残遗成分, 在地质 时期气候波动的影响下进一步演化、变迁形成了现 代分布格局。古近纪古植物群研究表明, 罗霄山脉 北段曾受干旱气候带的严重影响, 发展成为副热带 干旱植物区, 而南段则孕育出常绿-落叶阔叶林植 被型(陶君容,1992)。这里所指的常绿-落叶阔叶林植 被型，与Wolfe (1975)提出的第三纪北方热带植物 群中温植物 (mesotherms flora), 以及现代亚热带起 源性质的华夏植物区系(张宏达, 1962)是相一致的。 以现代分布中心在南岭、云贵高原地区的常绿植物 为代表, 如罩树属(Altingia)、水丝梨属(Sycopsis)、
秀柱花属(Eustigma)、茶梨属(Anneslea)、五列木属 (Pentaphylax)、马蹄荷属(Exbucklandia)、木莲属 (Manglietia)、棱果花属、油杉属(Keteleeria)等，属 于热带亚洲分布的子遗属, 这可能是第三纪时期的 北方热带植物区系成分向罗霄山脉渗入的结果。

青藏高原抬升之后, 东亚季风气候逐步形成 (An et al, 2001, Sun \& Wang, 2005), 中国中部的干 旱带范围西移(陶君容, 2000), 使得罗霄山脉地区进 一步成为北极-第三纪成分和北热带成分的交汇、

保存中心。北极-第三纪植物群是晚白严纪和古近 纪时期分布于泛北极地区的落叶阔叶林植被 (Engler, 1879; Chaney, 1947; Mai, 1991), 在中新世 以来的气候波动的影响下逐渐破碎化, 其现代分布 区类型呈现出泛北极、东亚一欧洲-北美间断分布、 东亚北美间断分布、东亚分布、北美分布、欧亚分 布等模式(Mai，1991)。罗霄山脉分布的子遗属中, 如胡桃属(Juglans)、七叶树属(Aesculus)、山茱英属 (Cornus)、冷杉属(Abies)、我掌楸属(Liriodendron)、 紫茎属(Stewartia)、银钟花属、金钱松属、蓝果树 属(Nyssa)、檫木属(Sassafras)、枳椇属(Hovenia)、 刺楸属(Kalopanax)、金缕梅属(Hamamelis)等均是北 极-第三纪植物群的特征性成分 (Engler, 1882; Chaney, 1947; 孙航，2002; 周浙昆和 Momohara, 2005), 其在中新世以来的全球气候整体降温的影 响下，因分布区逐渐缩减而残存至罗霄山脉地区。

第四纪的气候波动造成大陆东南部植被带向南 迁移，大量古老子遗属、特有属的分布区在冰期的影 响下，不断退缩至中国亚热带山地避难所(Harrison 
et al, 2001; Manchester et al, 2009; Wang et al, 2009)。 子遗种、古特有种的丰富程度是判断一个地区是否 为生物避难所的参考指标(胡忠俊, 2013), 廖文波等 (2014)针对井冈山、武夷山、峨眉山等地区子遗种的 丰富程度进行了比较, 认为地处罗霄山脉中段的井 冈山地区是重要的生物避难所。近年来针对银杉 (Cathaya argyrophylla) (Wang \& Ge, 2006)、大血藤 (Sargentodoxa cuneata) (Tian et al, 2015)、青钱柳属 (Kou et al, 2016)、皪木(Loropetalum chinense) (Gong et al, 2016)、血水草(Eomecon chionantha) (Tian et al, 2018)、福建柏(Yin et al, 2020)等子遗种的谱系地理学 研究, 亦证实罗霄山脉在冰期-间冰期是重要的生物 保存地及重新扩散的源头。

罗霄山脉地区植物区系的特有及残遗现象形 成受到了历史时期气候带变迁的强烈影响, 既保存 有丰富的北方热带植物群子遗成分, 同时也有丰富 的北极-第三纪子遗成分。这使得本地区种子植物 古特有属和子遗现象非常明显, 包括丰富的系统地 位孤立、古老的裸子植物、被子植物类群。尤其是 许多特征性的子遗植物群落, 如在低海拔地区保存 有大果马蹄荷 (Exbucklandia tonkinensis)、蕈树 (Altingia chinensis)、木莲(Manglietia fordiana)等季 雨林性质的常绿阔叶林群落; 中海拔分布有蓝果树 (Nyssa sinensis)、檫木(Sassafras tzumu)、伯乐树、 银钟花(Perkinsiodendron macgregorii) 等落叶性阔 叶林群落; 以及温性、暖温性的福建柏(Fokienia hodginsii)、穗花杉(Amentotaxus argotaenia)、资源 冷杉、银杉、长苞铁杉(Nothotsuga longibracteata) 等占优势的针叶林、针阔叶混交林群落。毫无疑问, 罗霄山脉尤其是其中、南段是一个典型避难所性质 的第三纪子遗植物群, 具有重要的生物多样性研究 和保护价值。

\section{参考文献}

An Z, Kutzbach JE, Prell WL, Porter SC (2001) Evolution of Asian monsoon and phased uplift of the Himalaya-Tibetan Plateau since late Miocene time. Nature, 411, 62-66.

APG IV (2016) An update of the Angiosperm Phylogeny Group classification for the orders and families of flowering plants: APG IV. Botanical Journal of the Linnean Society, 181, 1-20.

Chaney RW (1947) Tertiary centers and migration routes. Ecological Monographs, 17, 139-148.

Chang HD (1962) Floristic characteristics of Guangdong
Province. Acta Scientiarum Naturalium Universitatis Sunyatseni, 7(1), 1-34. (in Chinese with English abstract) [张宏达 (1962) 广东植物区系的特点. 中山大学学报(自 然科学版), 7(1), 1-34.]

Editorial Committee of Flora of Jiangxi (2004) Flora of Jiangxi (Vol. 2). China Science and Technology Press, Beijing. (in Chinese) [江西植物志编委会 (2004) 江西植物志 (第2 卷). 中国科学技术出版社, 北京.]

Editorial Committee of Flora of Jiangxi (2014) Flora of Jiangxi (Vol. 3). Jiangxi Science and Technology Press, Nanchang. (in Chinese) [江西植物志编委会 (2014) 江西植物志 (第 3卷). 江西科学技术出版社, 南昌.]

Engler A (1879) Versuch einer Entwicklungsgeschichte der Pflanzenwelt, insbesondere der Florengebiete seit der Tertiärperiode, 1. die extratropischen Gebiete der nördlichen Hemisphäre. Leipzig, W. Engelmann.

Engler A (1882) Versuch einer Entwicklungsgeschichte der Pflanzenwelt, insbesondere der Florengebiete seit der Tertiärperiode, Vol. Leipzig, W. Engelmann.

Feng G, Mao LF, Sandel B, Swenson N, Svenning J (2016) High plant endemism in China is partially linked to reduced glacial-interglacial climate change. Journal of Biogeography, 43, 145-154.

Gong Q, Liu WZ, Gu L, Kaneko S, Koch MA, Zhang DX (2016) From glacial refugia to wide distribution range: Demographic expansion of Loropetalum chinense (Hamamelidaceae) in Chinese subtropical evergreen broadleaved forest. Organisms Diversity and Evolution, 16, 23-38.

Habel JC, Assmann T (2010) Relict Species: Phylogeography and Conservation Biology. Springer-Verlag, New York.

Harrison SP, Yu G, Takahara H, Prentice IC (2001) Diversity of temperate plants in East Asia. Nature, 413, 129-130.

Hu ZJ, Zhang YL, Liu LS, Yu HB (2013) Refugia and their identification methods: A review. Chinese Journal of Ecology, 32, 3397-3406. (in Chinese with English abstract) [胡忠俊, 张镱理, 刘林山, 于海涁 (2013) 生物避难所及 其识别方法评述. 生态学杂志, 32, 3397-3406.]

Huang JH, Chen JH, Ying JS, Ma KP (2011) Features and distribution patterns of Chinese endemic seed plant species. Journal of Systematics and Evolution, 49, 81-94.

Huang JH, Ma KP, Chen B (2014) Diversity and Geographical Distributions of Chinese Endemic Seed Plants. Higher Education Press, Beijing. (in Chinese) [黄继红, 马克平, 陈 涁 (2014) 中国特有种子植物的多样性及其地理分布. 高等教育出版社, 北京.]

Ji CF, Qian P, Yang QP, Yang GY, Qiu LH, Yu F, Jie ZP (2010) Reaearch on floristic characteristics, geographical distributions and life-forms of plants endemic to Jiangxi Province. Journal of Wuhan Botanical Research, 28, 153-160. (in Chinese with English abstract) [季春峰, 钱萍, 杨清培, 杨光耀, 裴利洪, 于芬, 揭正平 (2010) 江西特 有植物区系、地理分布及生活型研究. 武汉植物研究, 28, 153-160.]

Kier G, Kreft H, Lee TM, Jetz W, Ibisch PL, Nowicki C, 
Mutke J, Barthlott W (2009) A global assessment of endemism and species richness across island and mainland regions. Proceedings of the National Academy of Sciences, USA, 106, 9322-9327.

Kou YX, Cheng SM, Tian S, Li B, Fan DM, Chen YJ, Soltis DE, Soltis PS, Zhang ZY (2016) The antiquity of Cyclocarya paliurus (Juglandaceae) provides new insights into the evolution of relict plants in subtropical China since the late Early Miocene. Journal of Biogeography, 43, 351-360.

Li BG, Liu LH (2010) Flora of Hunan (Vol. 3). Hunan Science and Technology Press, Changsha. (in Chinese) [李丙贵, 刘 林翰 (2010) 湖南植物志 (第3卷). 湖南科学技术出版社, 长沙.]

Li DZ, Chen ZD, Wang H, Lu AM (2018) A Dictionary of the Families and Genera of Chinese Vascular Plants. Science Press, Beijing. (in Chinese) [李德铢, 陈之端, 王红, 路安 民 (2018) 中国维管植物科属词典. 科学出版社, 北京.]

Liao QS, Liu JH, Xiong MZ (2008) The diversity and protection of the rare and endangered endemic plant species in Wugong Mountain. Journal of Pingxiang College, 25(3), 79-83. (in Chinese with English abstract) [廖铅生, 刘江华, 熊美珍 (2008) 萍乡市武功山稀有濒危、特有植物的多样 性及其保护. 萍乡高等专科学校学报, 25(3), 79-83.]

Liao WB, Wang YY, Li Z, Peng SL, Chen CC, Fan Q, Jia FL, Wang L, Liu WQ, Yin GS, Shi XG, Zhang DD (2014) Integrated Study on Biodiversity of Mount Jinggangshan Regions in China. Science Press, Beijing. (in Chinese) [廖文 波, 王英永, 李贞, 彭少麟, 陈春泉, 凡强, 贾凤龙, 王 蕾, 刘蔚秋, 尹国胜, 石祥刚, 张丹丹 (2014) 中国井冈 山地区生物多样性综合科学考察. 科学出版社, 北京.]

Liu KM (2000) Flora of Hunan (Vol. 2). Hunan Science and Technology Press, Changsha. (in Chinese) [刘克明 (2000) 湖南植物志 (第2卷). 湖南科学技术出版社, 长沙.]

Liu RL, Zhang ZX, Liao WM (2010) Plant List of Jiangxi Seed Plants. China Forestry Publishing House, Beijing. (in Chinese) [刘仁林, 张志翔, 廖为明 (2010) 江西种子植物 名录. 中国林业出版社, 北京.]

Lomolino MV, Riddle BR, Brown JH (2006) Biogeography. Sinauer Associates, Sunderland.

Mai DH (1991) Paleofloristic changes in Europe and the confurnation of the Arctotertiary-Paleotropical geofloral concept. Review of Palaeobotany and Palynology, 68, 29-36.

Manchester SR, Chen ZD, Lu AM, Uemura K (2009) Eastern Asian endemic seed plant genera and their paleogeographic history throughout the Northern Hemisphere. Journal of Systematics and Evolution, 47, 1-42.

Milne RL, Abbott RJ (2002) The origin and evolution of Tertiary relict flora. Advances in Botanical Research, 38, 281-314.

Qian H, Ricklefs RE (2004) Geographical distribution and ecological conservatism of disjunct genera of vascular plants in eastern Asia and eastern North America. Journal of Ecology, 92, 253-265.
Shen ZH, Zhang XS (2000) A quantitative analysis on the floristic elements of the Chinese subtropical region and their spatial patterns. Acta Phytotaxonomica Sinica, 38, 366-380. (in Chinese with English abstract) [沈泽昊, 张新时 (2000) 中国亚热带地区植物区系地理成分及其空间格局的数量 分析. 植物分类学报, 38, 366-380.]

Sun H (2002) Evolution of Arctic-Tertiary flora in Himalayan-Hengduan Mountains. Acta Botanica Yunnanica, 24, 671-688. (in Chinese with English abstract) [孙航 (2002) 北极-第三纪成分在喜马拉雅-横断山的发展及演 化. 云南植物研究, 24, 671-688.]

Sun XJ, Wang PX (2005) How old is the Asian monsoon system? Palaeobotanical records from China. Palaeogeography, Palaeoclimatology, Palaeoecology, 222, 181-222.

Tang CQ, Matsui T, Ohashi H, Dong YF, Momohara A, Herrando-Moraira Sonia, Qian SQ, Yang YC, Ohsawa M, Luu HT, Grote PJ, Krestov PV, LePage B, Werger M, Robertson K, Hobohm C, Wang CY, Peng MC, Chen X, Wang HC, Su WH, Zhou R, Li SF, He LY, Yan K, Zhu MY, Hu J, Yang RH, Li WJ, Tomita M, Wu ZL, Yan HZ, Zhang GF, He H, Yi SR, Gong HD, Song K, Song D, Li XS, Zhang ZY, Han PB, Shen LQ, Huang DS, Luo K, López-Pujol J (2018) Identifying long-term stable refugia for relict plant species in East Asia. Nature Communications, 9, 4488.

Tao JR (1992) The Tertiary vegetation and flora and floristic regions in China. Acta Phytotaxonomica Sinica, 30, 25-43. (in Chinese with English abstract) [陶君容 (1992) 中国第 三纪植被和植物区系历史及分区. 植物分类学报, 30, 25-43.]

Tao JR (2000) The Evolution of the Late Cretaceous-Cenozoic Floras in China. Science Press, Beijing. (in Chinese) [陶君 容 (2000) 中国晚白严世至新生代植物区系发展演变. 科学出版社, 北京.]

Tian L, Kou YX, Zhang Z, Yuan L, Li DR, López-Pujol J, Fan DM, Zhang ZY (2018) Phylogeography of Eomecon chionantha in subtropical China: The dual roles of the Nanling Mountains as a glacial refugium and a dispersal corridor. BMC Evolutionary Biology, 18, 20.

Tian S, Lei SQ, Hu W, Deng LL, Meng QL, Soltis DE, Soltis PS, Fan DM, Zhang ZY (2015) Repeated range expansions and inter-/postglacial recolonization routes of Sargentodoxa cuneata (Oliv.) Rehd. et Wils. (Lardizabalaceae) in subtropical China revealed by chloroplast phylogeography. Molecular Phylogenetics and Evolution, 85, 238-246.

Wang HS (1992) Floristic Geography. Science Press, Beijing. (in Chinese) [王荷生 (1992) 植物区系地理. 科学出版社, 北京.]

Wang HW, Ge S (2006) Phylogeography of the endangered Cathaya argyrophylla (Pinaceae) inferred from sequence variation of mitochondrial and nuclear DNA. Molecular Ecology, 15, 4109-4122.

Wang J, Gao PX, Kang M, Lowe AJ, Huang HW (2009) Refugia within refugia: The case study of a canopy tree (Eurycorymbus cavaleriei) in subtropical China. Journal of 
Biogeography, 336, 2156-2164.

Wang L, Liao WB, Chen CQ, Fan Q (2013) The seed plant flora of the Mount Jinggangshan region, Southeastern China. PLoS ONE, 8, e75834.

Wang LS, Jia Y, Zhang XC, Qin HN (2018) Species Catalogue of China (Vol. 1: Plants, A Synoptic Checklist I-III). Science Press, Beijing. (in Chinese) [王利松, 贾渝, 张宪 春, 覃海宁 (2018) 中国生物物种名录 (第一卷 植物 总 名录 I-III) 科学出版社, 北京.]

Wang W, Zhang XX, Chen ZD, Lu AM (2017) Comments on the APG's classification of angiosperms. Biodiversity Science, 25, 418-426. (in Chinese with English abstract) [王 伟, 张晓霞, 陈之端, 路安民 (2017) 被子植物APG分类 系统评论. 生物多样性, 25, 418-426.]

Wolfe JA (1975) Some aspects of plant geography of the Northern Hemisphere during the late Cretaceous and Tertiary. Annals of the Missouri Botanical Garden, 62, 264-279.

Wu ZY, Sun H, Zhou ZK, Li DZ, Peng H (2010) Floristics of Seed Plants from China. Science Press, Beijing. (in Chinese) [吴征镒, 孙航, 周浙昆, 李德铢, 彭华 (2010) 中国种子 植物区系地理. 科学出版社, 北京. ]

Wu ZY, Wu SG (1996) A proposal for a new floristic kingdom (realm)-The E. Asiatic kingdom, its delineation and characteristics. In: Floristic Characteristics and Diversity of East Asian Plants (eds Zhang AL, Wu SG), pp. 3-4Higer Education Press, Beijing, and Springer Verlag, Berlin.

Wu ZY, Zhou ZK, Sun H, Li DZ, Peng H (2006) The Areal-types of Seed Plants and Their Origin and Differentiation. Yunnan Science \& Technology Press, Kunming. (in Chinese) [吴征镒, 周浙昆, 孙航, 李德铢, 彭华 (2006) 种子植物分布区类型及其起源和分化. 云 南科技出版社, 昆明.]

Wullf EV, Brissenden E (1943) An Introduction to Historical Plant Geography. Chronica Botanica, Waltham.

Xie GW, Wang HY, Lai XR, Tan CM, Nong ZL (1995) Diversity and conservation of Chinese endemic genera of the flora in Jiuling-Mufu Mountains. Chinese Bulletin of Botany, 12, 90-95. (in Chinese with English abstract) [谢国 文, 汪红燕, 赖小荣, 谭策铭, 农植林 (1995) 九岭幕阜 山植物区系中的特有属的多样性及其保护. 植物学通报, 12, 90-95.]

Yin QY, Fan Q, Li P, Truong DV, Zhao WY, Zhou RC, Chen SF, Liao WB (2020) Neogene and Quaternary climate changes shaped the lineage differentiation and demographic history of Fokienia hodginsii (Cupressaceae s.l.), a Tertiary relict in East Asia. Journal of Systematics and Evolution, doi.org/10.1111/jse.12582.

Ying JS, Chen ML (2011) Plant Geography of China. Shanghai Science and Technology Press, Shanghai. (in Chinese) [应 俊生, 陈梦玲 (2011) 中国植物地理. 上海科学技术出版 社, 上海.]

Ying JS, Zhang YL (1994) Endemic Genus to Chinese Seed Plants. Science Press, Beijing. (in Chinese) [应俊生, 张玉 龙 (1994) 中国种子植物特有属. 科学出版社, 北京.]

Zhang GF (2001) Some notable questions of studies on flora-to discuss with Mr. Sun Ye-gen. Bulletin of Botanical Research, 21, 31-33. (in Chinese with English abstract) [张光富 (2001) 植物区系研究中值得注意的几 个问题——兼与孙叶根先生商榷. 植物研究, 21, 31-33.]

Zhao WY (2017) The Floristic Phytogeography of Spermatophyte Flora in Luoxiao Range. PhD dissertation, Sun Yat-sen University, Guangzhou. (in Chinese with English abstract) [赵万义 (2017) 罗霄山脉种子植物区系地理学 研究. 博士学位论文, 中山大学, 广州.]

Zhou ZK, Momohara A (2005) Fossil history of some endemic seed plants of East Asia and its phytogeographical significance. Acta Botanica Yunnanica, 27, 449-470. (in Chinese with English abstract) [周浙昆, Momohara A (2005) 一些 东亚特有种子植物的化石历史及其植物地理学意义. 云 南植物研究, 27, 449-470.]

(责任编委：王志恒 责任编辑：黄祥忠)

\section{附录 Supplementary Material}

\section{附录1 罗霄山脉种子植物区系的中国特有属}

Appendix 1 Chinese endemic genera of seed plants in the Luoxiao Mountains http://www.biodiversity-science.net/fileup/PDF/2019263-1.pdf

附录2 罗霄山脉种子植物区系的中国特有种

Appendix 2 Chinese endemic species of seed plants in the Luoxiao Mountains http://www.biodiversity-science.net/fileup/PDF/2019263-2.pdf

\section{附录3 罗霄山脉种子植物区系的子遗种}

Appendix 3 Relict species of seed plants in the Luoxiao Mountains http://www.biodiversity-science.net/fileup/PDF/2019263-3.pdf 